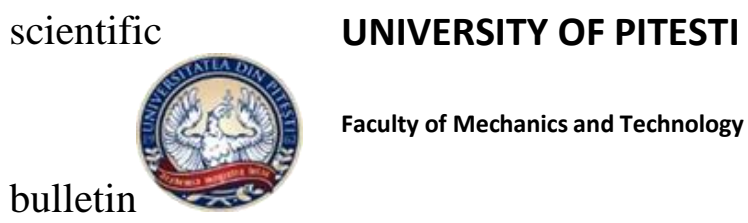

bulletin

\title{
An overview on metal-oxide catalytic converters
}

\author{
Ecaterina-Magdalena MODAN, Adriana-Gabriela PLĂIAȘU \\ University of Pitești, Romania \\ *Corresponding author e-mail: magdamodan@yahoo.com \\ Article history \\ Received 15.08 .2020 \\ Accepted 15.10 .2020 \\ DOI https://doi.org/10.26825/bup.ar.2020.002
}

\begin{abstract}
Diesel vehicles produce exhaust gases that include nitrogen oxides (NOx), carbon monoxide and hydrocarbons. A major environmental problem is the elimination of nitrogen oxides, as they are major air pollutants. Global restrictions on NOx emissions from fuel combustion have been imposed. Efforts have been made to develop catalysts for the selective catalytic reduction of NOx. In this paper is presented the types of catalytic converters used nowadays for dissipate emissions and selective catalytic reduction.
\end{abstract}

Keywords: catalytic converter, exhaust gas, two-way converter, three-way converter, selective catalytic reduction, catalysts

\section{Introduction}

Eugene Houdry, the french engineer, was the first one invented the catalytic converter. Later, catalytic converters were improved by other engineers, such as Carl Keith, John Mooney, Rodney Bagley and Irwin Lachman, making the first production of catalytic converters in 1973 [1-3]. The catalytic converter was introduced in 1975 on a large scale in automobiles to comply with the regulations on exhaust emissions. Catalytic converters are used to reduce pollutants. The main pollutants in the exhaust gases are carbon monoxide, hydrocarbons and nitrogen oxides.. Hydrocarbons and carbon monoxide occur due to incomplete gas mixing, as the combustion efficiency is $<100 \%$. Nitrogen oxides are formed during very high temperatures $\left(>1500^{\circ} \mathrm{C}\right)$ of the combustion process, causing the thermal fixation of nitrogen in the air. The chemical storage phase takes place during normal engine operation [4]. The exhaust gas temperature during the storage of nitrogen oxides varies from $150^{\circ} \mathrm{C}$ to $450^{\circ} \mathrm{C}$, depending on the engine operating point (speed and load). Nitrogen oxide is oxidized to form nitrogen dioxide $\left(\mathrm{NO}_{2}\right)$ [5]. Once the catalyst has reached the maximum storage capacity of nitrogen oxides (NOx), it proceeds to the regeneration phase. In this case, the engine runs on a rich mixture, the exhaust temperature being between $200^{\circ} \mathrm{C}-500^{\circ} \mathrm{C}$. The rich mixture is necessary for the presence of hydrocarbons ( $\mathrm{HC}$ ) and carbon monoxide (CO) in the catalyst, elements that contribute to the chemical reactions of reduction of nitrogen dioxide $\left(\mathrm{NO}_{2}\right)$ [6]. Photochemical reactions are triggered by the decomposition of $\mathrm{NO}_{2}$ into $\mathrm{NO}$ and atomic oxygen under the influence of light that reacts with hydrocarbons, which form ozone and various oxidation products presented in the reactions below: 
$\mathrm{NO}_{2} \rightarrow \mathrm{NO}+[\mathrm{O}](1)$

$\mathrm{O}+$ organic product $\rightarrow \mathrm{O}_{3}+$ reaction products (2)

$\mathrm{NOx}+\mathrm{HCs} \rightarrow \mathrm{O}_{3}+$ reaction products $(3)$

Exhaust emissions from the engine must be strictly controlled due to the consequences for the environment and health. The most effective way to control exhaust emissions are catalytic converters with different types of catalysts that convert the exhaust into water, carbon dioxide and nitrogen. Over time the catalysts have gone through several stages of development.

\section{Types of catalytic converters for car exhaust emissions}

The development of catalysis was initially associated with catalytic oxidation, and later as part of several chemical processes [7]. Due to the differences between gasoline and diesel in terms of exhaust environment, the oxidizing catalytic converter has developed in two directions as follows: gasoline applications have evolved from two-way converters to three-way converters; at the same time, oxidizing converters have progressed to diesel oxidation converters with other downstream pollution control devices responsible for reducing regulated emissions for diesel counterparts."Oxidizing" or "bidirectional" converters were the oldest converters that existed since the 1970s, as oxidations of hydrocarbons and carbon monoxide took place over the catalyst. Oxide emissions could not be controlled using these older converters. Because researchers had to focus on $\mathrm{HC}$ and $\mathrm{CO}$, standards for nitrogen oxide emissions were left out of the regulations. They came back in 1981, when the same catalytic system had to convert NOx to N2 [8]. This is how "oxidizing" or "bidirectional" converters have been replaced by three-way catalytic converters. For petrol vehicles, oxidizing converters were used for the first time to limit exhaust emissions. At that time, diesel cars were not required to have that technology because they already had low emissions of hydrocarbons and carbon monoxide [9]. On the other hand, the use of the oxidation catalyst has been extended to diesel cars as diesel oxidation catalysts [10]. Over diesel oxidation catalysts, $\mathrm{HC}$ and $\mathrm{CO}$ oxidation is clear, except that it has the role of converting $\mathrm{NO}$ to $\mathrm{NO} 2$, which participates in the regeneration of the particulate filter and improves the downstream NOx reduction process.

\subsection{The three-way catalyst}

When NOx emission standards came into force, the same catalytic system that supplemented oxygen to hydrocarbons and $\mathrm{CO}$ had to remove oxygen from $\mathrm{NOx}$ to result in nitrogen (N2). The first $\mathrm{NOx}$ reduction to $\mathrm{N} 2$ was performed on a platinum / rhodium catalyst [11]. A pump connected to the threeway catalyst supplies air between the oxidation and reduction catalysts. But this solution has not been technically and economically accepted. It has been observed that under certain favorable fuel conditions the platinum / rhodium catalyst can simultaneously convert $\mathrm{CO}$ and $\mathrm{HC}$ and reduce $\mathrm{NOx}$ with great efficiency. This catalyst approach has become known as a three-way catalyst (TWC) [11]. The transformation of the three pollutants into less harmful gases through a single TWC became feasible when the composition of the exhaust gases could be kept close to the stoichiometric point. At present, modern gasoline cars with three-way catalysts can achieve the elimination of exhaust gases [11]. 


\subsection{The two-way catalyst}

Patina-based catalysts have emerged as a solution for controlling catalytic emissions, which has led to a major reduction in hydrocarbon and carbon monoxide emissions [11]. Platinum deposited on the aluminum oxide substrate covered on a honeycomb support so that it can be placed on the exhaust manifold in front of the muffler, as close as possible to the engine [12]. These models were essentially bidirectional oxidation catalysts, as they helped both $\mathrm{HC}$ and $\mathrm{CO}$ react with the remaining oxygen in the exhaust having two simultaneous roles:

$\checkmark$ oxidation of $\mathrm{CO}$ in $\mathrm{CO}_{2}$;

$\checkmark$ oxidation of hydrocarbons to $\mathrm{CO} 2$ and $\mathrm{H}_{2} \mathrm{O}$.

$\mathrm{CO}+\mathrm{O}_{2} \rightarrow \mathrm{CO}_{2}(4)$

$\mathrm{HC}+\mathrm{O}_{2} \rightarrow \mathrm{CO}_{2}+\mathrm{H}_{2} \mathrm{O}(5)$

Until 1981, bidirectional catalytic oxidation converters were mainly used on petrol cars, and since then they have been replaced by three-way catalysts as they could not control nitrogen oxides [13].

\subsection{Diesel oxidation catalyst (doc)}

With the advent of regulations limiting harmful emissions into the atmosphere by diesel engines, the diesel oxidation catalyst (DOC) became part of diesel exhaust systems [14]. Volkswagen, one of the world's largest automakers, voluntarily introduced in 1989 the first DOC application on a new car, the Golf model "Umwelt with diesel engine adding platinum-based diesel oxidation catalysts, in a similar way to conventional two-way petrol catalysts [15] The emergence of the stricter Euro 3 standard (2000) has made this device mandatory for all diesel cars [16] The operating requirements for DOC are different from those for TWC, as the exhaust temperature for gasoline engines is usually higher than for diesel counterparts.DOCs operating at low temperatures have to Operate in lower temperature conditions have $2 \sim 3$ times the amount of catalytic material as a TWC for the same amount exhaust gas cleaning [17].

\subsection{Selective Catalytic Reduction (Scr)}

Through TWC, NOx is controlled from the release to the exhaust system in stoichiometric conditions [18]. Even so, it cannot achieve NOx elimination when gasoline and diesel engines have low combustion [19]. Currently, selective catalytic reduction is the main technical remedy for diesel [18]. The SCR reaction requires a reducing agent to control nitrogen oxides. NH3 one of the reductants selectively reduces $\mathrm{NO}_{\mathrm{X}}$ using specific catalysts [18]. In mobile applications, ammonia-smelling gas has had to be replaced with a precursor, such as urea that can be stored safely [18]. Other reducing agents have been proposed to avoid the handling of ammonia. SCRs can be classified according to the reductants used in three groups as follows: HC-SCR; $\mathrm{H}_{2}-\mathrm{SCR} ; \mathrm{NH}_{3}-\mathrm{SCR}$ [20]. Of the three categories mentioned above, the best choice is $\mathrm{NH}_{3}$-SCR. The use of urea to reduce the exhaust emissions of diesel engines has been applied since 1988 [21-23]. In 1985 urea was already used as a precursor for stationary SCR applications [24]. In 1990, the first researches on urea-mobile SCR were revealed. Due to the characteristics of urea (it is neither toxic nor corrosive) it is found in aqueous solutions, such as urea-water known as AdBlue ${ }^{\circledR}$, and is used for diesel applications. [25, 26].

Currently, major car manufacturers have adopted the option of adding urea solution to an additional tank so that it decomposes in the presence of hot gas flow after the solution is previously sprayed into the main exhaust pipe. 


\section{Types of materials used for catalysts}

The three main categories in which the catalysts used in the SCR process can be generally grouped as follows: noble metal-based catalysts; metal oxide catalysts and zeolite-based catalysts.

\subsection{Noble metal-based catalysts}

$\mathrm{Pd}, \mathrm{Pt}, \mathrm{Au}$ and $\mathrm{Rh}$ as noble metal catalysts are used as support $\mathrm{TiO}_{2}, \mathrm{ZrO}_{2}, \mathrm{SiO}_{2}$ and $\mathrm{Al}_{2} \mathrm{O}_{3}$, which are used for selective catalytic reduction. Noble metal catalysts have a higher activity and special properties at low temperatures. The disadvantage is that some of the $\mathrm{NH}_{3}$ will be oxidized by the noble metal catalyst, and the SCR system that uses this type of catalyst will increase the cost of the system. The basic reaction process is NO deoxidation at the active site of the Pt catalyst, and Pt-O is limited by reduction [27]. Zhang et al. synthesized by the impregnation method a series of catalysts supported with $\mathrm{TiO}_{2}$ with $0.5 \%$ by weight of noble metal $(\mathrm{Pd}, \mathrm{Pt}, \mathrm{Ru}$ and $\mathrm{Rh})$ using propylene as a reductant. They studied catalysts by comparing their catalytic performance. The results of the experiment showed that the highest catalytic activity was the $\mathrm{Pt} / \mathrm{TiO}_{2}$ catalyst had. For the $\mathrm{Pt} / \mathrm{TiO}_{2}$ catalyst the elimination rate was $63 \%$ at $140^{\circ} \mathrm{C}$, achieving $100 \%$ of the propylene conversion. At temperatures of $200^{\circ} \mathrm{C}$ and $225^{\circ} \mathrm{C}$ respectively, the $\mathrm{NOx}$ removal rates of $\mathrm{Pd} / \mathrm{TiO}_{2}$ and $\mathrm{Ru} / \mathrm{TiO}_{2}$ catalysts were lower than those at $140^{\circ} \mathrm{C}$ for the $\mathrm{Pt} / \mathrm{TiO}_{2}$ catalyst. The conversion rate of propylene was in the order of $\mathrm{Pt}$ $/ \mathrm{TiO}_{2}\left(160^{\circ} \mathrm{C}\right)>\mathrm{Pd} / \mathrm{TiO}_{2}\left(240^{\circ} \mathrm{C}\right)>\mathrm{Ru} / \mathrm{TiO}_{2}\left(250^{\circ} \mathrm{C}\right)>\mathrm{Rh} / \mathrm{TiO}_{2}\left(300^{\circ}\right)>\mathrm{TiO}_{2}\left(350^{\circ} \mathrm{C}\right)$. The results of the experiment showed that the specific surface area of the catalyst produced by impregnation synthesis was smaller than that of hollow $\mathrm{TiO}_{2}$, and this can be explained by the fact that the noble metal has a less specific surface area. As the temperature increased, the conversion rate from NO to $\mathrm{NO}_{2}$ increased. In the low temperature range the $\mathrm{Pt} / \mathrm{TiO} 2$ catalyst had higher oxidability than other catalysts. [28, 29].

Yang et al. synthesized the $\mathrm{Pt} / \mathrm{Al}_{2} \mathrm{O}_{3}$ catalyst by impregnation synthesis and studied the effect of $\mathrm{Pt}$ temperature and load on the reaction. The results showed that only $\mathrm{N}_{2} \mathrm{O}$ was formed from low chemisorbed $\mathrm{NO}$ molecules at Pt. Compared to $\mathrm{N}_{2} \mathrm{O} \mathrm{N}_{2}$ formation was specific at temperatures above $80{ }^{\circ} \mathrm{C}[30]$.

Valanidou et al together with Olympiou et al. synthesized the catalysts $\mathrm{Pt} / \mathrm{MgO}-\mathrm{CeO}_{2}$ and $\mathrm{Ag} / \mathrm{MgO}-$ $\mathrm{CeO}_{2}-\mathrm{Al}_{2} \mathrm{O}_{3}$, respectively. The results showed that the catalysts showed a high $\mathrm{NO}$ conversion rate, selectivity and high $\mathrm{N}_{2}$ stability. After 48 hours of reaction in flow, the active sites of the catalyst were not affected by the presence of $\mathrm{SO}_{2}$, which shows a high stability of the $\mathrm{Ag} / \mathrm{MgO}-\mathrm{CeO}_{2}-\mathrm{Al}_{2} \mathrm{O}_{3}$ catalyst $[31,32]$.

\subsection{Oxide materials for catalysts}

The most efficient catalysts for $\mathrm{NH}_{3}-\mathrm{SCR}$ are those based on metal oxides whereas the use of Pt-based catalysts has been quite limited as its optimal temperature range is small [33]. Due to their excellent activity, selectivity and stability of $\mathrm{V}_{2} \mathrm{O}_{5}-\mathrm{WO}_{3} / \mathrm{TiO}_{2}$ catalysts have been intensively studied [33]. Their major disadvantages are high activity for unwanted oxidation of $\mathrm{SO}_{2}$, high toxicity of vanadium and inefficiency at low and high temperatures [34]. For the SCR process the most used catalyst is $\mathrm{V}_{2} \mathrm{O}_{5}$ dispersed on the $\mathrm{TiO}_{2}$ anatase support promoted by $\mathrm{WO}_{3}$ (and /or $\mathrm{MoO}_{3}$ ). In general, the total surface area of the catalysts is 50-100 m²/g, with a $\mathrm{V}_{2} \mathrm{O}_{5}$ content of $0.5-3 \%$ and a $\mathrm{MoO}_{3}$ or $\mathrm{WO}_{3}$ content of 5$10 \%$. Studies conducted in IR and Raman show that vanadium, tungsten and molybdenum species are present on the surfaces of these catalysts [35]. For automotive applications the catalyst should cover a wide range of temperatures, because during the cold start the engine is low and during the exotherm regeneration of the particulate filter is increased.. 
Iron oxide, as a catalyst, has been intensively studied in recent years due to its characteristics, namely, low toxicity and thermal stability [36].

For example, Shen et al. used the sol-gel method to dopate $\mathrm{Mn}-\mathrm{Ce} / \mathrm{TiO}_{2}$ with iron to elaborate a Fe$\mathrm{Mn}-\mathrm{Ce} / \mathrm{TiO}_{2}$ catalyst. $\mathrm{Fe}$ addition has been shown to improve $\mathrm{NH}_{3}-\mathrm{SCR}$ activity at low catalyst temperature [37].

Liu et al. developed $\alpha-\mathrm{Fe}_{2} \mathrm{O}_{3}$ and $\gamma-\mathrm{Fe}_{2} \mathrm{O}_{3}$ powder by coprecipitation synthesis and compared the catalytic activity and selectivity of both phases of ferric oxide under the same conditions. The results showed that at a temperature between $150-300{ }^{\circ} \mathrm{C}$ higher catalytic activity had the catalyst $\gamma-\mathrm{Fe}_{2} \mathrm{O}_{3}$. Ammonia and nitrogen oxide were adsorbed and reacted easily with $\gamma-\mathrm{Fe}_{2} \mathrm{O}_{3}$. Impairment of the SCR reaction occurred by blocking active sites due to nitrate formation [38]. Wang et al. they synthesized the $\mathrm{Fe}_{2} \mathrm{O}_{3}$ powder by the aqueous precipitation method. The results showed that due to the present $\mathrm{SO}_{2}$ the deactivation of $\mathrm{Fe}_{2} \mathrm{O}_{3}$ took place and in 6 hours the $\mathrm{NO}$ conversion decreased from $99.2 \%$ to $58 \%$, as $\mathrm{SO}_{2}$ gradually decreased the activity of the catalysts. The results showed that the suppression of catalytic activity can be explained by the inactivation caused by $\mathrm{SO}_{2}$ which is due to the formation of metal sulfates and ammonium sulfates on the surface of the catalyst during the chemical reaction [39].

\subsection{Zeolite-based catalysts}

Recently, zeolite-based catalysts are becoming more and more interesting, especially zeolite-based catalysts with metal ion exchange, such as Fe-ZSM-5 and Cu-ZSM-5, because has high activity and durability [40].

Delahay et al. investigated both Fe zeolite and zeolitic systems. The results showed that ironexchanged zeolites showed activity at high temperatures, and those replaced with copper had a good activity below $300^{\circ} \mathrm{C}$, because above $350^{\circ} \mathrm{C}$, NO conversion decreases due to the oxidation process of ammonia [41,42].

Schay et al. developed a series of Cu-ZSM-5 catalysts and their studies showed that a catalyst with a copper ion exchange of $132 \%$ at a temperature of $300^{\circ} \mathrm{C}$, the maximum conversion of $\mathrm{NO}$ was $70 \%$, and at a temperature between $200 \mathrm{oC}$ and $300^{\circ} \mathrm{C}$ its catalytic activity was better than those with $88 \%$ copper ion exchange. As the exchange of copper ions increases, the number of oxidations increases, which leads to the formation of $\mathrm{NO}_{3}$-type surface complexes of the active intermediate. The catalytic activity of the Cu-ZSM-5 catalyst has been improved [43].

$\mathrm{Li}$ et al. investigated metal oxide catalysts, zeolite $(\mathrm{Fe} / \mathrm{Cu})$ and the reaction mechanism of NH3-SCR and showed that the resistance of metal oxide based on $\mathrm{H}_{2} \mathrm{O}$ and $\mathrm{SO}_{2}$ based on $\mathrm{Mn}$ is a major problem for its use at low temperatures [44].

In the literature, the authors are reluctant to use zeolite-type catalysts for the direct decomposition of $\mathrm{NO}$ because they show low $\mathrm{SO}_{2}$ resistance.

\section{Conclusions}

Catalytic converters have been used in vehicle emissions control for many years, e.g., three-way catalytic (TWC) converters in spark-ignition engines during the past several decades and DOCs in diesel engines since the 1990s. Catalytic converters are used to reduce exhaust gases. Exhaust gases contain hydrocarbons, carbon monoxide and nitrogen oxides. The most effective way to control exhaust emissions are catalytic converters with different types of catalysts that convert the exhaust gas into water, carbon dioxide and nitrogen. The catalyst efficiency reduces at high exhaust flow rate and also the catalyst ages over time. Selective catalytic reduction can be classified according to the reductants used in three groups as follows: HC-SCR; H2-SCR; NH3-SCR. The catalysts used in the SCR process can be generally classified as follows: noble metal catalysts; metal oxide catalysts and zeolite-based catalysts.The catalyst types could be a base metal (e.g., copper, $\mathrm{Cu}$, or chromium, $\mathrm{Cr}$ ) 
but are more usually noble metal (platinum, Pt, palladium, Pd, rhodium, Rh). The transition metal oxides of copper, cobalt, iron chromate, and vanadium are also useful as catalysts and have been considered.

\section{References}

[1] Bera P, Hegde M. Recent advances in auto exhaust catalysis. Journal of the Indian Institute of Science. 2010;90(2):299-325.

[2] Hall CW. A Biographical Dictionary of People in Engineering: From the Earliest Records Until 2000: Purdue University Press; 2008.

[3] Vessel SP. Corning Researchers Honored for Pollution-Control Invention. Journal of Failure Analysis and Prevention. 2005;5:4.

[4] Majewski W, Khair M. Commercial DOC Technologies. Revision; 2011.

[5] Nova I, Tronconi E. Urea-SCR technology for deNOx after treatment of diesel exhausts: Springer; 2014.139.

[6] Skalska K, Miller JS, Ledakowicz S. Trends in NOx abatement: A review. Science of the total environment. 2010;408(19):3976-89.

[7] Twigg MV. Rôles of catalytic oxidation in control of vehicle exhaust emissions.Catalysis Today. 2006;117(4):407-18

[8] Klepetar D. Technology-Forcing and Law-Forcing: The California Effect in Environmental Regulatory Policy. 2012.

[9] Auvray X. Fundamental studies of catalytic systems for diesel emission control: Chalmers University of Technology; 2013.

[10] Zelenka P, Cartellieri W, Herzog P. Worldwide diesel emission standards, current experiences and future needs. Applied Catalysis B: Environmental. 1996;10(1):3-28.

[11] Twigg MV. Progress and future challenges in controlling automotive exhaust gas emissions. Applied Catalysis B: Environmental. 2007;70(1-4):2-15

[12] Platinum Matthey. Palladium use in diesel oxidation catalysts. Available online: http://www.platinum.matthey.com/documents/market-review/2009/special

featuredownloads/palladium-use-in-diesel-oxidation-catalysts-.pdf

[13] Khajepour A, Fallah MS, Goodarzi A. Electric and Hybrid Vehicles: Technologies, Modeling and Control-A Mechatronic Approach: John Wiley \& Sons; 2014.

[14] Russell A, Epling WS. Diesel Oxidation Catalysts. Catalysis Reviews.2011;53(4):337-423.

[15] Zelenka P, Ostgathe K, Lox E. Reduction of Diesel Exhaust Emissions by Using Oxidation Catalysts. SAE International; 1990.

[16] Majewski W, Khair M. Commercial DOC Technologies. Revision; 2011

[17] Haaß F, Fuess H. Structural characterization of automotive catalysts. Advanced Engineering Materials. 2005;7(10):899-913.

[18] Nova I, Tronconi E. Urea-SCR technology for deNOx after treatment of diesel exhausts: Springer; 2014.

[19] Skalska K, Miller JS, Ledakowicz S. Trends in NOx abatement: A review. Science of the total environment. 2010;408(19):3976-89.

[20] Roy S, Hegde MS, Madras G. Catalysis for NOx abatement. Applied Energy. 2009;86(11):228397.

[21] Iwamoto M, Hamada H. Removal of nitrogen monoxide from exhaust gases through novel catalytic processes. Catalysis Today. 1991;10(1):57-71.

[22] Yokota K, Fukui M, Tanaka T. Catalytic removal of nitric oxide with hydrogen and carbon monoxide in the presence of excess oxygen. Applied Surface Science. 1997;121:273-7.

[23] Savva PG, Costa CN. Hydrogen Lean-DeNOx as an Alternative to the Ammonia and Hydrocarbon Selective Catalytic Reduction (SCR). Catalysis Reviews. 2011;53(2):91- 151.

[24] Costa CN, Efstathiou AM. Mechanistic Aspects of the $\mathrm{H}_{2}-\mathrm{SCR}$ of $\mathrm{NO}$ on a Novel Pt/MgO-CeO Catalyst. The Journal of Physical Chemistry C. 2007;111(7):3010-20. 
[25] Liu Z, Ihl Woo S. Recent Advances in Catalytic DeNOX Science and Technology. Catalysis Reviews. 2006;48(1):43-89.

[26] Held W, König A, Richter T, Puppe L. Catalytic NOx Reduction in Net Oxidizing Exhaust Gas. SAE International; 1990.

[27] Q. Xu, Z.J. Zheng, C.M. Ling: Environment Pollution and Control, Vol.33(2011), p81

[28] Z.X. Zhang, M.X. Chen: Low-temperature SCR of NO with propylene in excess oxygen over the $\mathrm{Pt} / \mathrm{TiO}_{2}$ catalyst Catalysis Communications, Vol.10 (2009), p1330

[29] Z.X. Zhang, M.X. Chen: Performance and mechanism study for low-temperature SCR of NO with propylene in excess oxygen over Pt/TiO ${ }_{2}$ catalyst Journal of Environmental Sciences, Vol. 22 (2010), p1441

[30] J. Yang, H. Jung: Environment Pollution and Control, Vol.33(2011), p81

[31] G. G. Olympiou, A. M. Efstathiou: Industrial NOx control via $\mathrm{H}_{2}-\mathrm{SCR}$ on a novel supported-Pt nanocatalyst, Chemical Engineering Journal, Vol.170 (2011), p424

[32] L. Valanidou, C. Theologides: Applied Catalysis B: Environmental, Vol.107 (2011), p164

[33] Pârvulescu VI, Grange P, Delmon B. Catalytic removal of NO. Catalysis Today. 1998;46(4):233316.

[34] Moliner M, Franch C, Palomares E, Grill M, Corma A. Cu-SSZ-39, an active and hydrothermally stable catalyst for the selective catalytic reduction of NOx. Chemical Communications. 2012;48(66):8264-6.

[35] Busca G, Larrubia MA, Arrighi L, Ramis G. Catalytic abatement of NOx: Chemical and mechanistic aspects. Catalysis Today. 2005;107-108:139-48

[36] Husnain, N.; Wang, E.; Li, K.; Anwar, M.T.; Mehmood, A.; Gul, M.; Li, D.; Jinda, M. Iron oxide-based catalysts for low-temperature selective catalytic reduction of $\mathrm{NOx}$ with $\mathrm{NH}_{3}$. Rev. Chem. Eng. 2019, 35, 239-264.

[37]Shen, B.; Liu, T.; Zhao, N.; Yang, X.; Deng, L. Iron-doped Mn-Ce/TiO 2 catalyst for low temperature selective catalytic reduction of $\mathrm{NO}$ with $\mathrm{NH}_{3}$. J. Environ. Sci. 2010, 22, 1447-1454

[38]Liu, C.; Yang, S.; Ma, L.; Peng, Y.; Hamidreza, A.; Chang, H. Comparison on the performance of $\alpha-\mathrm{Fe}_{2} \mathrm{O}_{3}$ and $\gamma-\mathrm{Fe}_{2} \mathrm{O}_{3}$ for selective catalytic reduction of nitrogen oxides with ammonia. Catal. Lett. 2013, 143, 697-704.

[39]Wang, X.; Gui, K. $\mathrm{Fe}_{2} \mathrm{O}_{3}$ particles as superior catalysts for low temperature selective catalytic reduction of $\mathrm{NO}$ with $\mathrm{NH}_{3}$. J. Environ. Sci. 2013, 25, 2469-2475.

[40] Iwasaki M, Yamazaki K, Banno K, Shinjoh H. Characterization of Fe/ZSM-5 DeNOx catalysts prepared by different methods: Relationships between active Fe sites and NH3-SCR performance. Journal of Catalysis. 2008;260(2):205-16.

[41]G. Delahay, D. Valade, A. Guzmán-Vargas, B. Coq, Selective catalytic reduction of nitric oxide with ammonia on Fe-ZSM-5 catalysts prepared by different methods Appl. Catal. B: Environ.55(2005)149- 155.

[42]C. Torre-Abreu, C. Henriques, F. R. Ribeiro, G. Delahay, M. F. Ribeiro, Selective catalytic reduction of $\mathrm{NO}$ on copper-exchanged zeolites: the role of the structure of the zeolite in the nature of copper-active sites Catal. Today.54(1999) 407-418.

[43] Z. Schay, L. Guczi, A. Beck, I. Nagy, V. Samuel, S. P. Mirajkar and G. Pa'1-Borbe'ly, Catal. Today, DeNOx reactions on Cu-zeolites: Decomposition of $\mathrm{NO}, \mathrm{N}_{2} \mathrm{O}$ and $\mathrm{SCR}$ of $\mathrm{NO}$ by $\mathrm{C}_{3} \mathrm{H}_{8}$ and $\mathrm{CH}_{4}$ on Cu-ZSM-5 and Cu-AlTS-1 catalysts2002, 75, 393-399.

[44] Li, J.; Chang, H.; Ma, L.; Hao, J.; Yang, R.T. Low-temperature selective catalytic reduction of NOxwith NH3over metal oxide and zeolite catalysts-A review.Catal. Today2011,175, 147-156 